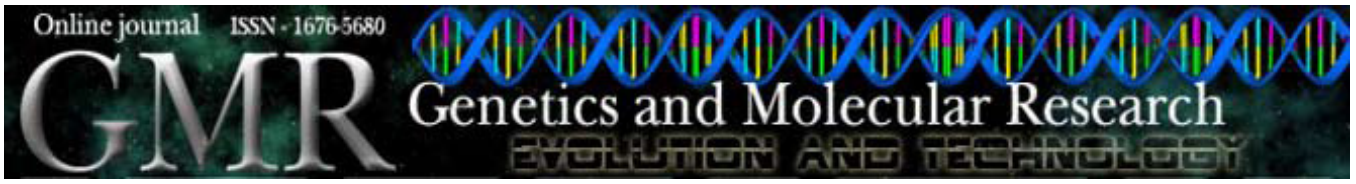

\title{
Enhancer/Suppressor mutator (En/Spm)-like transposable elements of cassava (Manihot esculenta) are transcriptionally inactive
}

\author{
M.A. Gbadegesin and J.R. Beeching \\ Department of Biology and Biochemistry, University of Bath, Bath, \\ United Kingdom \\ The present address of M.A. Gbadegesin is Department of Biochemistry, \\ Molecular Biology Unit, University of Ibadan, Ibadan, Nigeria \\ Corresponding author: M.A. Gbadegesin \\ E-mail: magbadegesin@yahoo.com
}

Genet. Mol. Res. 9 (2): 639-650 (2010)

Received December 16, 2009

Accepted January 6, 2010

Published April 13, 2010

DOI 10.4238/vol9-2gmr713

\begin{abstract}
Transposable elements contribute to the size, structure, variation, and diversity of the genome and have major effects on gene function. Sequencing projects have revealed the diversity of transposable elements in many organisms and have shown that they constitute a high percentage of the genome. PCR-based techniques using degenerate primers designed from conserved enzyme domains of transposable elements can provide quick and extensive surveys, making study of diversity and abundance and their applications possible in species where full genome sequence data are not yet available. We studied cassava (Manihot esculenta) $\underline{E}$ / $\underline{S} p m$-like transposons (Meens) with regard to genomic distribution, sequence diversity and methylation status. Cassava transposase fragments characteristic of En/Spm-like transposons were isolated, cloned and characterized. Sequence analysis showed that cassava $\mathrm{En} / \mathrm{Spm}$-like elements are highly conserved, with overall identity in the range of $68-98 \%$. Southern hybridization supports the presence of multiple copies of $\mathrm{En} / \mathrm{Spm}$-like transposons integrated in the genome of all cassava cultivars that we tested. Hybridization patterns of HpaII- and MspI-digested cassava genomic DNA revealed highly methylated sequences. There were no clear differences in hybridization
\end{abstract}


pattern between the cultivars. We did not detect RNA transcripts of Meens by Northern procedures. We examined the possibility of recent transposition activities of the cassava En/Spm-like elements.

Key words: Cassava; Transposable elements; Transposon; En/Spm

\section{INTRODUCTION}

Transposable elements (TEs) have been classified into two major superfamilies according to their transposition intermediate and transposition mechanisms (Finnegan, 1992). Class I elements (retrotransposons or retroelements) move and amplify through RNA intermediates, which are reverse transcribed before their integration into the nuclear genome. They are the most widespread class of eukaryotic TEs (SanMiguel et al., 1996; Lander et al., 2001). Class II elements (DNA TEs) move by excision and reintegration via a DNA intermediate; they transpose by a "cut and paste" mechanism mediated by a transposase that recognizes their short terminal inverted repeated (TIRs) sequences. Enhancer/Suppressor mutator (En/Spm) TEs belong to this class.

Peterson (1953) and McClintock (1954) independently discovered the En/Spm TE system. Peterson named the autonomous element Enhancer (En), while McClintock called it Suppressor-mutator (Spm). Autonomous TEs consist of sequences that are required in cis for transposition and express trans-acting proteins, whereas the non-autonomous elements do not express these proteins and can only transpose if the proteins are supplied by an autonomous element elsewhere in the genome. The non-autonomous element is called Inhibitor/defective Suppressor-mutator (I/dSpm). En/Spm is the most thoroughly studied member of the CACTA TE superfamily. The characteristic features of the CACTA elements are the presence of TIRs terminating with the sequence CACTA and the creation of 3-bp TSDs. Figure 1 summarizes the structural features of $E n / S p m$ of maize.

$\mathrm{En} / \mathrm{Spm}$ transposons have proved to be useful in the isolation of many maize and Antirrhinum genes (Luo et al., 1991; Tissier et al., 1999). They have the advantage of exhib-

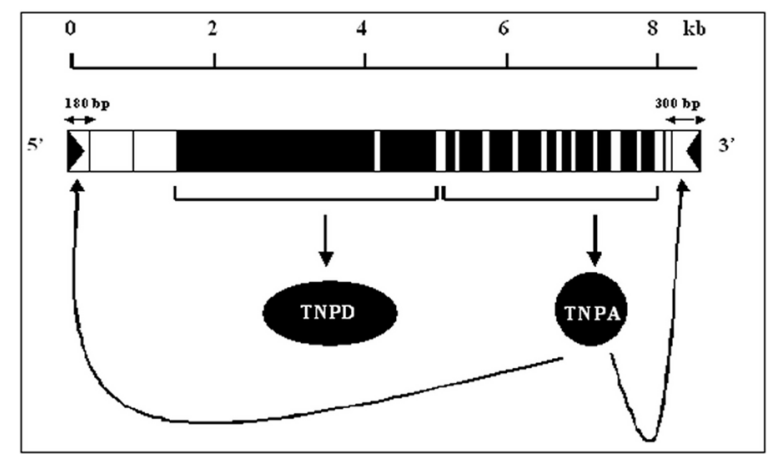

Figure 1. Structural organization of Enhancer/Suppressor mutator $(E n / S p m)$ of maize. En/Spm is an $\sim 8.3-\mathrm{kb}$ DNA transposon flanked at the termini by terminal inverted repeats (TIRs) shown as triangles. Exon sequences for the two genes of En/Spm are shown as shaded boxes: TnpD codes for the gene product TNPD or the transposase, while TnpA codes for TNPA. The open boxes represent the introns. TNPA protein binds to the sub-terminal sequence motifs (each $12 \mathrm{bp}$ ), which are scattered within $\sim 180 \mathrm{bp}$ at the 5' end (nine) and $\sim 300 \mathrm{bp}$ at the 3' end (fifteen) shown. At the 5' end, the most internal of the TNPA binding motifs overlaps with the TATA box, which exists as TATGAA in En/Spm. 
iting frequent reversion of the disrupted gene to wild-type due to excision of the transposon. Suppression, a phenomenon characterized by the ability of an active transposon to change the degree of the phenotype produced by an insertion without excision, is another attribute of En/Spm, which may contribute to tagging effectiveness. This depends on the TnpA gene product of En/Spm, which acts by binding at the sub-termini of En/Spm or I/dSpm elements and interfering with transcription of the host gene (Grant et al., 1990, 1993).

$\mathrm{En} / \mathrm{Spm}$ has successfully been exploited as a tool for functional genomics in Arabidopsis by using it to generate mutant lines (Wisman et al., 1998; Tissier et al., 1999; Speulman et al., 1999). The present study assessed the presence and activity of En/Spm-like transposons in cassava. En/Spm-like transposons could be used to elucidate the apparently subtle actions of genes and might have potential as a tool for genomic analysis and biotechnological development of cassava. To date, there has not been any published information as to the presence and nature of $\mathrm{En} / \mathrm{Spm}$-like transposons in cassava.

\section{MATERIAL AND METHODS}

\section{Plant material}

Young leaf samples for the isolation of DNA and total RNA were obtained from various cassava cultivars. Cassava plants were grown in the tropical glasshouse at the University of Bath at $22-28^{\circ} \mathrm{C}$, with a relative humidity of $40-80 \%$ and a minimum light period of $12 \mathrm{~h}$ per day under daylight, supplemented with $400 \mathrm{~W}$ Phillips high-pressure sodium lights when necessary.

\section{PCR amplification of transposase fragment of cassava $\mathrm{En} / \mathrm{Spm}$-like sequences and cloning}

The polymerase chain reaction (PCR) method used was as described by Staginnus et al. (2001), with some modifications as follows: 50 - or 100- $\mu$ L PCR mixes contained 50 pmol of each primer, $0.5 \mathrm{mM}$ dNTPs, $3 \mathrm{mM} \mathrm{MgCl}$, and $250 \mathrm{ng}$ template DNA, using a PCR cycle of $94^{\circ} \mathrm{C}(2 \mathrm{~min}), 35$ times [at $94^{\circ} \mathrm{C}$ for $1 \mathrm{~min}, 55^{\circ} \mathrm{C}$ for $1 \mathrm{~min}$ and $72^{\circ} \mathrm{C}$ for $1 \mathrm{~min}$ ], and at $72^{\circ} \mathrm{C}$ for 5 min. Amplified DNA bands were gel purified (Qiagen, Qiaquik), ligated into PGEM $^{\circledR}-T$ Easy vector (Promega) and used to transform competent Escherichia coli DH5 $\alpha$ according to standard procedures (Sambrook et al., 1989).

\section{DNA gel blot analysis}

Cassava genomic DNA was isolated from young leaves by the method of Dellaporta et al. (1983). Restriction digestions of genomic DNA (5 $\mu \mathrm{g}$ each) were carried out using buffer and reaction conditions specified by the manufacturer (Promega). Blotting and hybridization were performed using standard procedures (Sambrook et al., 1989).

\section{DNA sequencing and sequence analyses}

DNA molecules were sequenced on an ABI 337 automated dye primer sequencer using universal primers for the cloning vector. Initial confirmation of sequence identity was by BLASTN and TBLASTX searches against the GenBank non-redundant database 
using the default parameters (Altschul et al., 1990). Sequence data were aligned using CLUSTAL W (version 1.82) (Thompson et al., 1994).

\section{Wounding and incubation procedures}

Wounding stress was induced in cassava leaves with a modified method of Takeda et al. (1998). In one set of experiments, leaf discs were prepared by cutting young cassava (cultivar MCOL22) leaves into discs of approximately $1 \mathrm{~cm}^{2}$. In a second, the leaf segments prepared from young leaves were stabbed with the points of a forceps about twenty times. The leaf segments (stabbed or unstabbed) were then incubated on $0.05 \% 2$-[N-morpholino] ethane sulfonic acid (MES)-KOH buffer, $\mathrm{pH} 5.7$, at $25^{\circ} \mathrm{C}$ under ambient light. MES is generally used in tissue culture to prevent oxidative degradation of biomolecules. Leaf samples were taken at $2,4,6,8,12,24$, and $48 \mathrm{~h}$ from the incubation mix, rapidly wrapped with aluminum foil and submerged in liquid nitrogen. These were immediately ground to a fine powder with a mortar and pestle and the powdered leaves stored at $-70^{\circ} \mathrm{C}$ until required. Total RNA was isolated from the powdered samples of leaves as below. For the root, the conditions for deterioration experiments were as described by Han et al. (2001).

\section{RNA extraction and Northern blot procedures}

Using 2-mL nuclease-free microfuge tubes, RNA was extracted from the homogenized tissue using the Promega SV total RNA isolation system with some modifications to the specifications of the manufacturer as follows: $350 \mu \mathrm{L}$ lysis buffer was added to $0.09 \mathrm{~g}$ of the ground tissue in the microfuge tube and mixed by inversion. RNA dilution buffer $(700 \mu \mathrm{L})$ was then added and the contents again mixed by inversion before centrifugation at $13,000 \mathrm{rpm}$ for $10 \mathrm{~min}$. The cleared lysate solution was then transferred to a fresh microfuge tube by pipetting without disturbing the pelleted debris, and the centrifugation step was repeated. A volume of $400 \mu \mathrm{L} 95-100 \%$ ethanol was added to the clear lysate and mixed by pipetting four times. The mixture was then transferred to the spin column assembly and spun at 13,000 rpm for $1 \mathrm{~min}$. The rest of the protocol followed procedure E (RNA purification by centrifugation) of the kit manufacturer (Promega). Total RNA was extracted from cassava storage roots using the method of Chang et al. (1993).

Ten micrograms total RNA per lane was electrophoresed on a $1.5 \%$ agarose gel containing formaldehyde and blotted onto a nylon membrane (Hybond $\mathrm{N}+$, Amersham), according to standard procedures (Sambrook et al., 1989). Hybridizations were carried out at $65^{\circ} \mathrm{C}$ overnight, after which membranes were washed at a final wash stringency of $0.2 \mathrm{X} \mathrm{SSC}, 0.2 \%$ SDS for $20 \mathrm{~min}$ at $65^{\circ} \mathrm{C}$. The membranes were then exposed to Fuji X-ray film and incubated at $-70^{\circ} \mathrm{C}$, and the autoradiograph was then developed.

The nucleotide sequences described here have been submitted to the GenBank database and given the accession numbers AY946045-AY946084.

\section{RESULTS}

\section{PCR amplification of cassava $\mathrm{En} / \mathrm{Spm}$ transposase fragment, cloning and sequence analysis}

PCR was carried out as described in the Material and Methods section above. The 
amplified products were analyzed by electrophoresis on ethidium bromide stained $1.0 \%$ agarose gels (Figure 2).

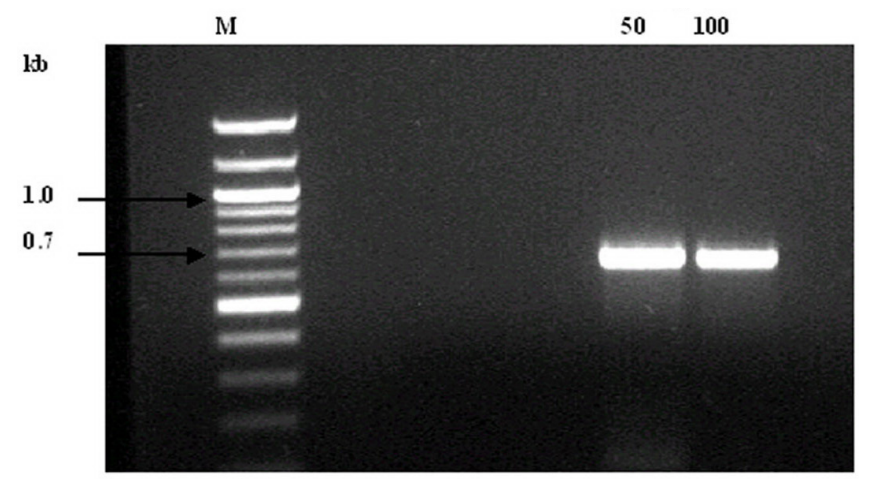

Figure 2. Polymerase chain reaction (PCR) amplification of $E n / S p m$-like transposase fragment from cassava genomic DNA. The PCR product was run on a 1.0\% agarose gel stained with ethidium bromide. The size marker (lane M) is Bioline DNA 100-bp ladder while the PCR product for 50 - and $100-\mu \mathrm{L}$ reaction mixes are shown in the right lanes.

Approximately 650-bp putative fragments of the transposase domain were amplified in PCR. The DNA band was gel purified, and the purified DNA was sequenced directly using the PCR primers. The PCR product sequence was then submitted to BLASTN and TBLASTX searches. These confirmed that an En/Spm-like transposon fragment had been amplified in the PCR experiments. The cassava element was $67 \%$ identical (within the region of the alignment) to the En/Spm-like transposon of Daucus carota (accession number AB071202) at the amino acid sequence level (Figure 3). The cassava sequence $(\mathrm{Me})$ had unresolved ambiguous nucleotides within the overall sequence. This ambiguity suggested that the PCR band represents a population of diverse individual members of $E n / S p m$-like transposons. Subsequent to cloning, randomly selected clones were fully sequenced. These sequences showed clear homology to the transposase of En/Spm-like transposons (in most cases E-values from BLAST searches were in the region of $\mathrm{E}^{-63}$ ).

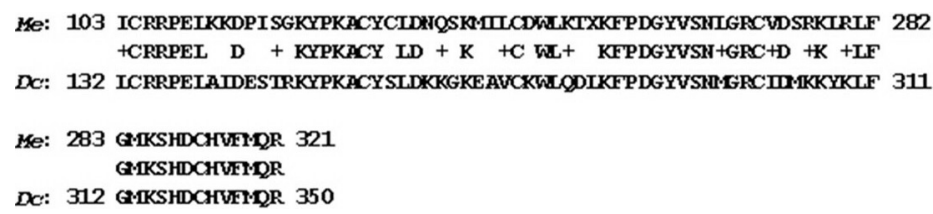

Figure 3. Alignment of amino acid sequence of cassava Meen $(M e)$ polymerase chain reaction product with that of Daucus carota $(D c) E n / S p m$-like transposon-transposase (accession number AB071202). The two sequences share 67\% identity.

\section{Phylogenetic analysis}

The nucleotide sequences of 40 unique clones representing cassava $\mathrm{En} / \mathrm{Spm}$-like transposons (Meens) were aligned using CLUSTAL W and highlighted in GENDOC version 2.3 (Figure 4). The alignment showed that there is a high degree of nucleotide sequence conservation among the cassava En/Spm-like transposons with overall identity in the range of $68-98 \%$. 

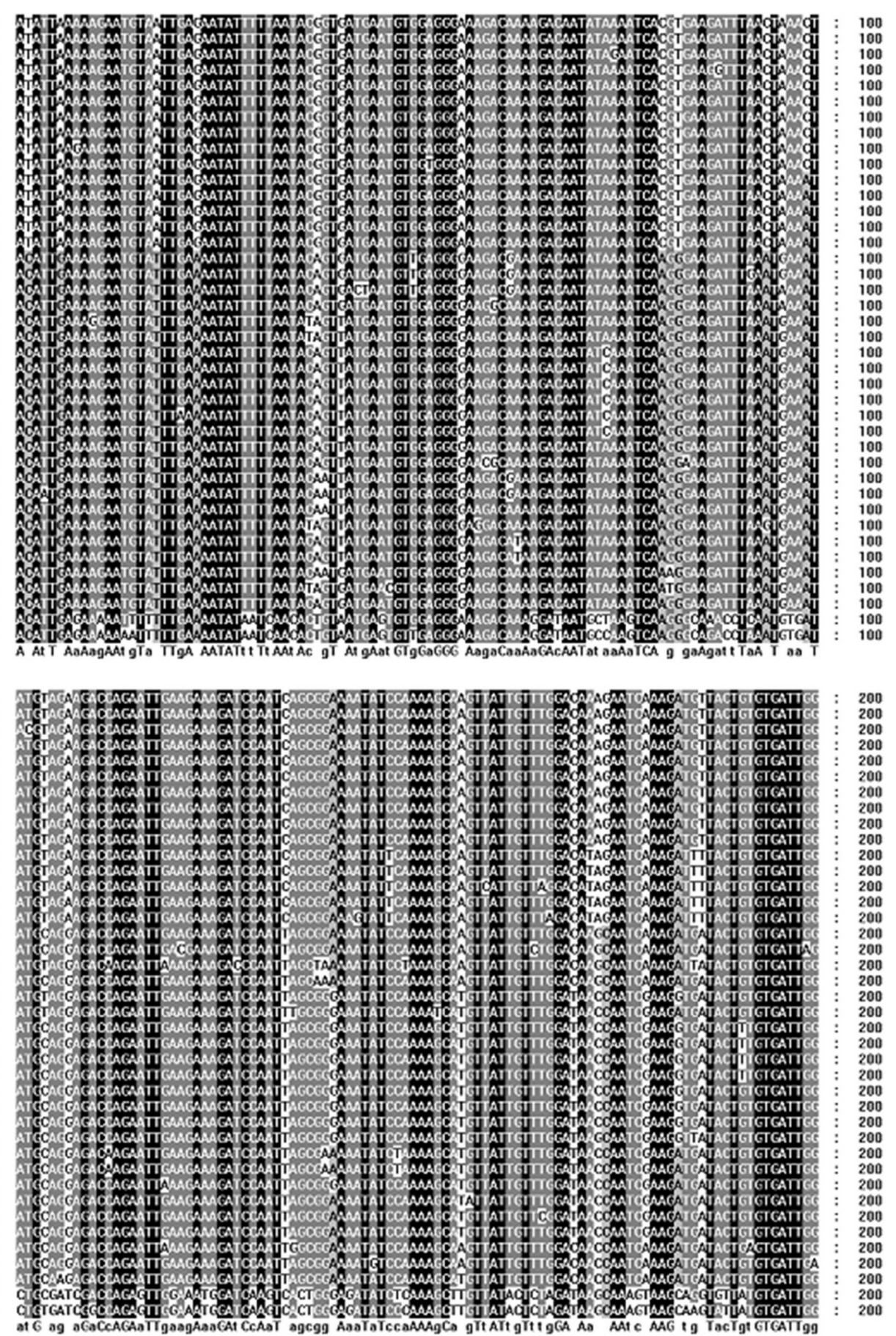

Continued on next page 
Figure 4. Continued.
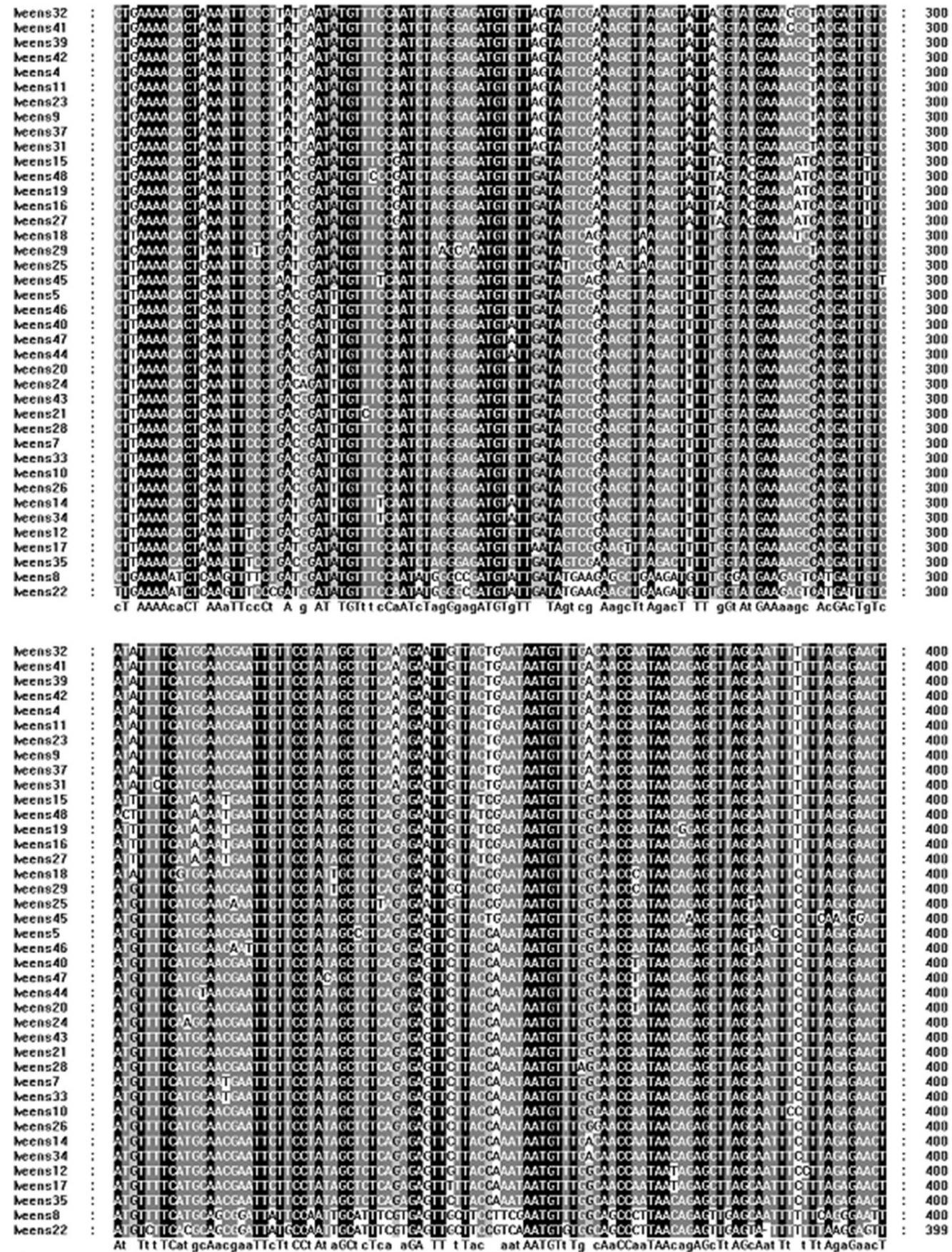

400
400
400
400
400
400
400
400
400
400
400
400
400
400
400
400
400
400
400
400
400
400
400
400
400
400
400
400
400
400
400
400
400
400
400
400
400
400
400
400
400
400
499
490

Continued on next page 

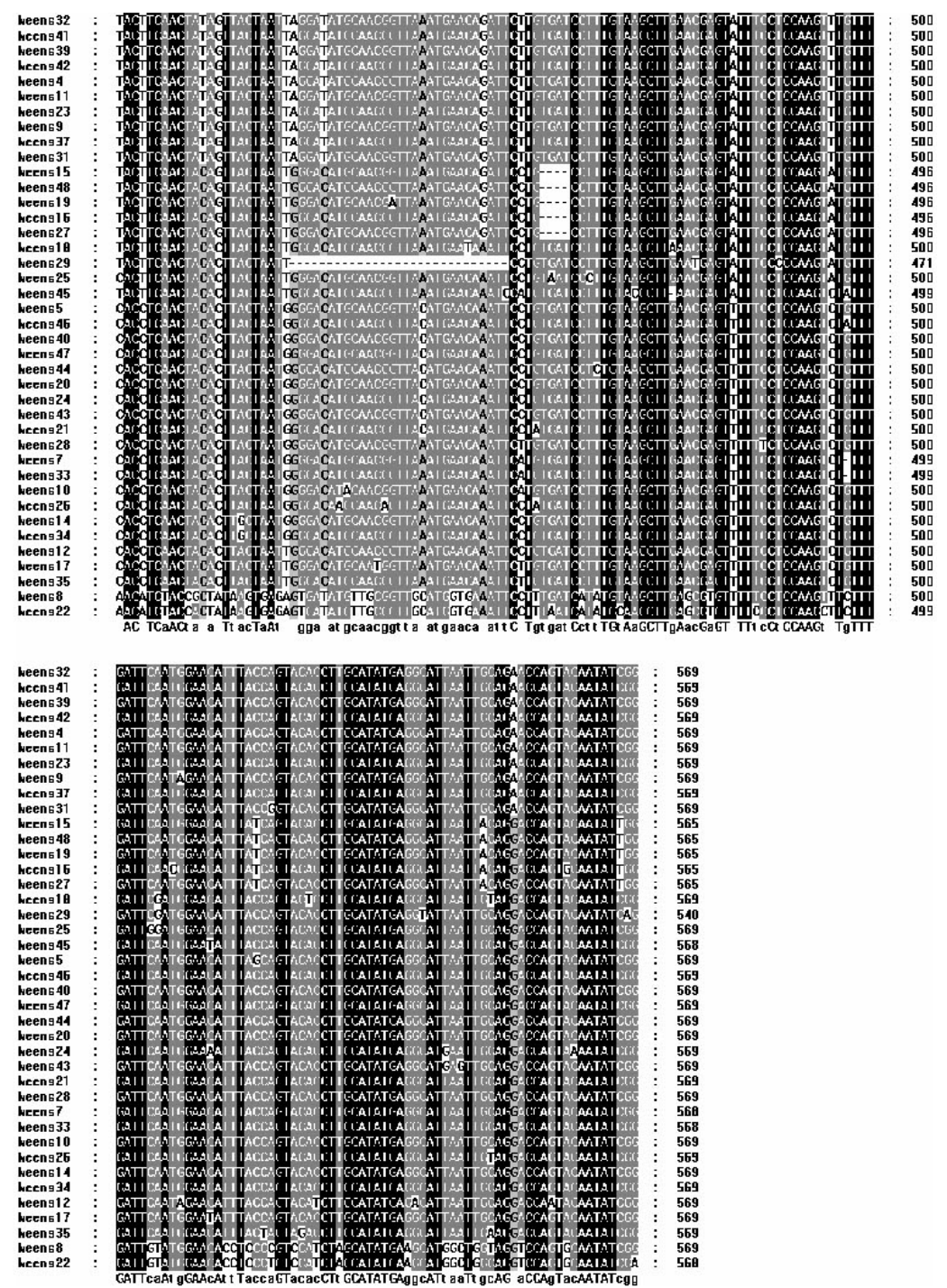

Figure 4. Multiple sequence alignment of the nucleotide sequences for 40 transposase fragments of cassava $E n /$ Spm-like transposons (Meens). The sequences were aligned using the CLUSTAL W program. Gaps (indicated with dashes) represent deletions in the sequence. Color blocking (done in GENDOC) indicates sequence conservation: Black $=100 \%$ identity, grey $=60-80 \%$ and non-shaded $=<60 \%$ identity.

\section{Study on the genomic organization and diversity of $\mathrm{En} / \mathrm{Spm}$-like transposons in cassava cultivars}

In order to gain an insight into the genomic organization of the cassava $\mathrm{En} / \mathrm{Spm}$-like transposons, a representative cassava element, Meens 5, was used to probe a Southern blot of the DNA from 10 different cassava cultivars separately digested with BglII, HindIII and EcoRI 
(see Figure 5). Strong signals were obtained, revealing the presence of multiple bands after a short exposure time, which suggests that many copies of Meens and relatives were integrated in the genome. Incomplete digestion of the genomic DNA was ruled out because the same gel blot probed with a well-characterized sequence showed only few distinct hybridizing bands (data not shown). The data also suggest that Meens 5 cross hybridizes with sequences highly homologous to the probe, represented by the strong major bands, as well as related diverged fragments, seen as weak signals. The digests did not reveal clear differences in the hybridization pattern between the cultivars tested (Figure 5, Panels a, b and c).

$M 1234567890112$

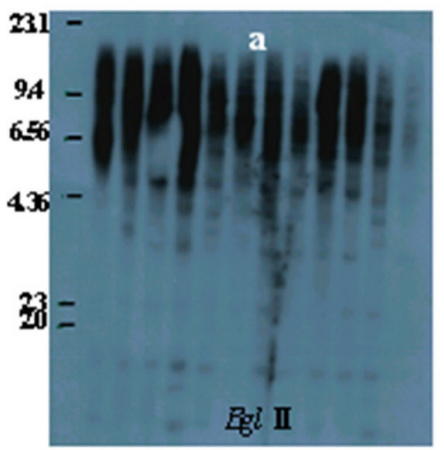

$M 123456789101112$

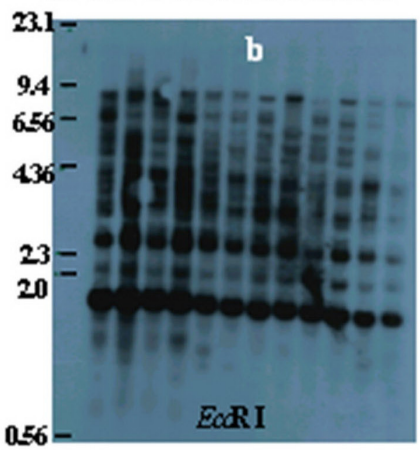

M 123456789101112

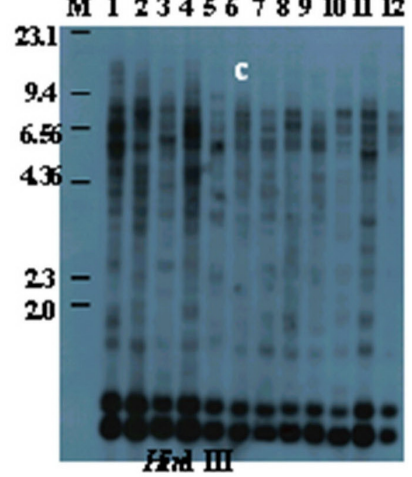

Figure 5. Southern blot analysis of En/Spm-like transposase of 12 cassava cultivars. Each cassava cultivar was carried out with $10 \mu \mathrm{g}$ genomic DNA. Lane 1 (MGA1), lane 2 (MNGA2), lane 3 (MDOM5), lane 4 (MNGA19), lane 5 (MCOL22), lane 6 (CMC40), lane 7 (MVEN77), lane 8 (CG402), lane 9 (SM627), lane 10 (SM985), lane 11 (SM1088), and lane 12 (CM2177) were digested with BglII (a), EcoRI (b) or HindIII (c). The digested DNAs were separated on $0.8 \%$ agarose gels, transferred to a nylon membrane and hybridized with the Meens 5 probe. HindIII-digested lambda DNA was used as a DNA size marker (M).

\section{Methylation status and transcriptional activity of $\mathrm{En} / \mathrm{Spm}$-like transposons of cassava}

To determine the methylation status of cassava En/Spm-like transposons, Meens 5 was used to probe Southern blots of the DNA from 10 different cassava cultivars digested with $H p a \mathrm{II}$ or MspI. The hybridization pattern in most cases showed a strong smear over a range of low to high molecular weights (Figure 6). These sequences were probably highly methylated as revealed by minor differences between the hybridization pattern of the HpaII and MspI digests. These two enzymes share the recognition nucleotide base sequence CCGG, but HpaII is blocked by methylation at either C, while MspI is blocked by methylation at the external $\mathrm{C}$ only. The finding here suggests the presence of only few unmethylated external cytosine residues in the sequence CCGG of cassava En/Spm-like transposons, and therefore completely or near completely methylated sequences. In addition, when Meens 5 was used to probe the Northern blot of total RNA prepared from cassava leaves and roots, as described in the Material and Methods section, there were no detectable signals in the hybridizations. 


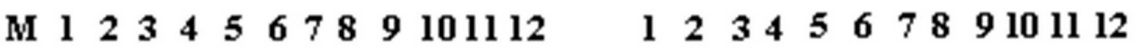

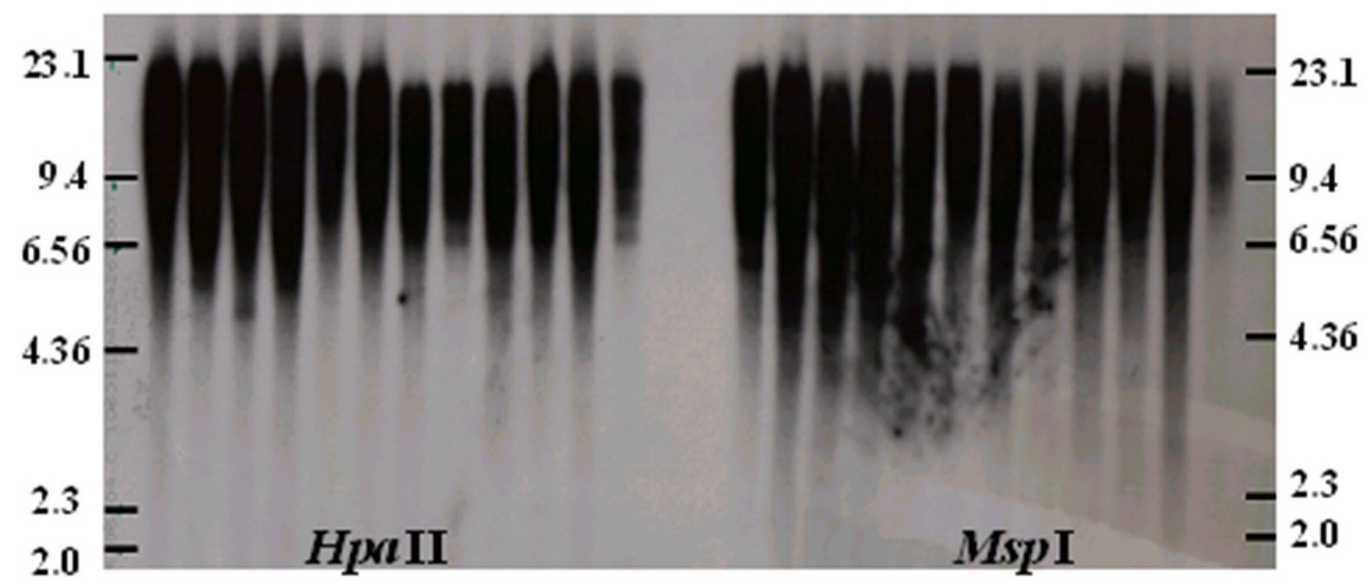

FIGURE 6. Methylation status of En/Spm-like transposase of 12 cassava cultivars. A total of $10 \mu \mathrm{g}$ genomic DNA from each of the cassava cultivars (as in Figure 5) was digested with HpaII or MspI. The digested DNAs were separated on $0.8 \%$ agarose gels, transferred to a nylon membrane and hybridized with the Meens 5 probe. HindIIIdigested lambda DNA was used as a DNA size marker (M).

\section{DISCUSSION}

Using PCR degenerate primers, cassava transposase fragments characteristic of $E n /$ Spm-like transposons were isolated, cloned and sequenced. Alignment of the nucleotide sequences of cassava En/Spm-like transposon clones (Meens) showed that there was a high level of nucleotide sequence conservation among the cassava elements. The alignment of the putative peptide sequence of representative Meens with known En/Spm-like transposons of other plants (data not shown) revealed identity at most positions that were conserved in the majority of the elements compared.

These findings for Meens are similar to those observed for the En/Spm transposons of Arabidopsis thaliana, Solanum lycopersicum and Elaeis guineensis. However, more diverged sequences of En/Spm-like transposons were reported for Cicer arietinum (Staginnus et al., 2001). An extreme case of divergence of $\mathrm{En} / \mathrm{Spm}$ transposons within a plant has been reported for the nucleotide sequences of carrot (Daucus carota), where the $T d c C$ element was found to be highly divergent from the other two families, $T d c A$ and $T d c B$ (Itoh et al., 2003).

Our Northern blot hybridizations of total RNA did not produce detectable signals. This suggests that the cassava En/Spm-like elements are transcriptionally inactive or their transcripts were produced at such a low level that they were not detectable here. We found, from the deduced translations of the cassava $\mathrm{En} / \mathrm{Spm}$-like transposon-transposase, that $72.5 \%$ contain a frame shift, a nonsense mutation or both within the sequence analyzed. Therefore, the majority of these cassava enzymes would be non-functional and defective.

Southern blot analysis did not reveal clear differences in the hybridization pattern between the cultivars tested (Figure 5, Panels a, b and c, and Figure 6). The observations made with cassava elements, Meens, suggest that they have not been active during the recent history of cassava. The same restriction enzyme digest blots probed with cassava 
Mutator-like transposable element (MULE) transposase cDNA show clear polymorphism among the same cassava cultivars (Gbadegesin et al., 2007). The hybridization pattern of the Meens in most cases, especially with the HpaII or MspI digestion of the genomic DNA, showed a strong smear over a range of low to high molecular weights (Figure 6). This indicates the presence of Meen 5 and homologues in many different genomic loci. These sequences were probably highly methylated as revealed by minor differences between the hybridization pattern of the HpaII and MspI digests. In contrast to the above, Southern analyses of the DNA digested by the isoschizomers, HpaII and MspI, revealed partial methylation sequences of cassava Mutator-like transposable elements for the same set of cultivars (Gbadegesin et al., 2007). These findings lend strong support to the association between decreases in DNA methylation and increased activity of transposable elements.

DNA methylation has tremendous effects on the heritability and activity of $\mathrm{En} / \mathrm{Spm}$ (Banks et al., 1988). It is a key component of the mechanism that regulates transposition (Chandler and Walbot, 1986; Chomet et al., 1987; Fedoroff et al., 1995; Singer et al., 2001; Lisch et al., 2002). Transposons induce changes in host genes, some of which are detrimental (Zabala and Vodkin, 2007; Begin and Schoen, 2007; Beare et al., 2009). DNA methylation is especially important in plants, and mutants with reduced levels of cytosine methylation display highly abnormal developmental phenotypes (Finnegan et al., 1996; Kakutani et al., 1996; Ronemus et al., 1996). In conclusion, cassava EnSpm-like transposons are highly methylated, transcriptionally inactive and may not have been active during the recent history of cassava.

\section{ACKNOWLEDGMENTS}

M.A. Gbadegenin would like to acknowledge funding from the Commonwealth Scholarship Commission, UK. This publication is supported by University of Ibadan Senate Research Grant No. SRG/COM/2006/35A. It is also in part an output from a research project funded by the United Kingdom Department for International Development (DFID) for the benefit of developing countries: R8156 Crop Post-Harvest Programme. The views expressed are not necessarily those of DFID. This study has been carried out in compliance with the current laws governing genetic experimentation in the UK.

\section{REFERENCES}

Altschul SF, Gish W, Miller W, Myers EW, et al. (1990). Basic local alignment search tool. J. Mol. Biol. 215: 403-410.

Banks JA, Masson P and Fedoroff N (1988). Molecular mechanisms in the developmental regulation of the maize Suppressor-mutator transposable element. Genes Dev. 2: 1364-1380.

Beare PA, Unsworth N, Andoh M, Voth DE, et al. (2009). Comparative genomics reveal extensive transposon-mediated genomic plasticity and diversity among potential effector proteins within the genus Coxiella. Infect. Immun. 77: 642-656.

Begin M and Schoen DJ (2007). Transposable elements, mutational correlations, and population divergence in Caenorhabditis elegans. Evolution 61: 1062-1070.

Chandler VL and Walbot V (1986). DNA modification of a maize transposable element correlates with loss of activity. Proc. Natl. Acad. Sci. U. S. A. 83: 1767-1771.

Chang S, Puryear J and Cairney J (1993). A simple and efficient method for isolating RNA from pine trees. Plant Mol. Biol. Rep. 11: 113-116.

Chomet PS, Wessler S and Dellaporta SL (1987). Inactivation of the maize transposable element Activator (Ac) is associated with its DNA modification. EMBO J. 6: 295-302.

Dellaporta SL, Wood J and Hicks JB (1983). A plant DNA minipreparation: Version II. Plant Mol. Biol. Rep. 1: 19-21.

Fedoroff N, Schlappi M and Raina R (1995). Epigenetic regulation of the maize Spm transposon. Bioessays 17: 291-297. 
Finnegan DJ (1992). Transposable elements. Curr. Opin. Genet. Dev. 2: 861-867.

Finnegan EJ, Peacock WJ and Dennis ES (1996). Reduced DNA methylation in Arabidopsis thaliana results in abnormal plant development. Proc. Natl. Acad. Sci. U. S. A. 93: 8449-8454.

Gbadegesin MA, Gómez-Vásquez R, Reilly K and Beeching JR (2007). Transcriptionally active mutator-like transposable elements in the genome of Cassava (Manihot esculenta Crantz). Asian J. Plant Sci. 6: 129-136.

Grant SR, Gierl A and Saedler H (1990). En/Spm encoded tnpA protein requires a specific target sequence for suppression. EMBO J. 9: 2029-2035.

Grant SR, Hardenack S, Trentmann S and Saedler H (1993). Functional cis-element sequence requirements for suppression of gene expression by the TNPA protein of the Zea mays transposon En/Spm. Mol. Gen. Genet. 241: 153-160.

Han Y, Gómez-Vásquez R, Reilly K, Li H, et al. (2001). Hydroxyproline-rich glycoproteins expressed during stress responses in cassava. Euphytica 120: 59-70.

Itoh Y, Hasebe M, Davies E, Takeda J, et al. (2003). Survival of Tdc transposable elements of the En/Spm superfamily in the carrot genome. Mol. Genet. Genomics 269: 49-59.

Kakutani T, Jeddeloh JA, Flowers SK, Munakata K, et al. (1996). Developmental abnormalities and epimutations associated with DNA hypomethylation mutations. Proc. Natl. Acad. Sci. U. S. A. 93: 12406-12411.

Lander ES, Linton LM, Birren B, Nusbaum C, et al. (2001). Initial sequencing and analysis of the human genome. Nature 409: 860-921.

Lisch D, Carey CC, Dorweiler JE and Chandler VL (2002). A mutation that prevents paramutation in maize also reverses Mutator transposon methylation and silencing. Proc. Natl. Acad. Sci. U. S. A. 99: 6130-6135.

Luo D, Coen ES, Doyle S and Carpenter R (1991). Pigmentation mutants produced by transposon mutagenesis in Antirrhinum majus. Plant J. 1: 59-69.

McClintock B (1954). Mutations in maize and chromosomal aberrations in Neurospora. Carnegie Inst. Washington Yearbook 53: 254-261.

Peterson PA (1953). A mutable pale green locus in maize. Genetics 38: 682-683.

Ronemus MJ, Galbiati M, Ticknor C, Chen J, et al. (1996). Demethylation-induced developmental pleiotropy in Arabidopsis. Science 273: 654-657.

Sambrook J, Fritsch E and Maniatis T (1989). Molecular Cloning: A Laboratory Manual. Cold Spring Harbor Laboratory Press, Cold Spring Harbor.

SanMiguel P, Tikhonov A, Jin YK, Motchoulskaia N, et al. (1996). Nested retrotransposons in the intergenic regions of the maize genome. Science 274: 765-768.

Singer T, Yordan C and Martienssen RA (2001). Robertson's Mutator transposons in A. thaliana are regulated by the chromatin-remodeling gene Decrease in DNA Methylation (DDM1). Genes Dev. 15: 591-602.

Speulman E, Metz PL, van ArKel G, te Lintel HB, et al. (1999). A two-component enhancer-inhibitor transposon mutagenesis system for functional analysis of the Arabidopsis genome. Plant Cell 11: 1853-1866.

Staginnus C, Huettel B, Desel C, Schmidt T, et al. (2001). A PCR-based assay to detect En/Spm-like transposon sequences in plants. Chromosome Res. 9: 591-605.

Takeda S, Sugimoto K, Otsuki H and Hirochika H (1998). Transcriptional activation of the tobacco retrotransposon Tto1 by wounding and methyl jasmonate. Plant Mol. Biol. 36: 365-376.

Thompson JD, Higgins DG and Gibson TJ (1994). CLUSTAL W: improving the sensitivity of progressive multiple sequence alignment through sequence weighting, position-specific gap penalties and weight matrix choice. Nucleic Acids Res. 22: 4673-4680.

Tissier AF, Marillonnet S, Klimyuk V, Patel K, et al. (1999). Multiple independent defective suppressor-mutator transposon insertions in Arabidopsis: a tool for functional genomics. Plant Cell 11: 1841-1852.

Wisman E, Cardon GH, Fransz P and Saedler H (1998). The behaviour of the autonomous maize transposable element En/ Spm in Arabidopsis thaliana allows efficient mutagenesis. Plant Mol. Biol. 37: 989-999.

Zabala G and Vodkin L (2007). Novel exon combinations generated by alternative splicing of gene fragments mobilized by a CACTA transposon in Glycine max. BMC Plant Biol. 7: 38. 